\title{
CONSIDERING EFFECTS OF CLIMATE EXTREMES ON PLANT FUNCTIONAL TRAITS BENEFITS THE PREDICTION OF ECOSYSTEM FUNCTIONING
}

\author{
GUO, T. ${ }^{*}$ - TANG, Y. H. \\ College of Urban and Environmental Sciences, Peking University, 100871 Beijing, China \\ ${ }^{*}$ Corresponding author \\ e-mail: tongg@pku.edu.cn \\ (Received $11^{\text {th }}$ Apr 2019; accepted $13^{\text {th }}$ Jun 2019)
}

\begin{abstract}
Climate extremes are recognized as main drivers of ecosystem functioning in terrestrial biomes. So far impacts and underlying mechanisms of which climate extremes shape ecosystem processes are poorly understood. This gap impedes an understanding of how climatic extremes modulate long-term and large landscape provisions of ecosystem functions. Trait-based studies render a feasible avenue that links climate extremes and ecosystem functioning. Plant functional traits are considered as a sensitive probe in terms of the response to changes in climatic conditions. Approaches that account for effects of climate extremes on plant functional traits may close this gap. We develop a stepwise framework that relates the response of functional traits to climate extremes and resolves relationships between patterns of functional traits and ecosystem functioning by a process-based dynamic vegetation model. We introduce an ongoing case study to demonstrate how this framework permits an accurate evaluation of ecosystem functioning under various scenarios of climate extremes. Our proposed framework may benefit functioning programs by providing key functional traits sensitive to climate extremes or determinants of ecosystem functions. The practice will in turn improve the parameterization and the validation of the vegetation model, especially in regions paucity of field data.
\end{abstract}

Keywords: dynamic vegetation model, ecosystem process, patterns of functional traits, precipitation, temperature, alpine ecosystems

\section{Introduction}

The intensity and the frequency of climatic extremes, namely abnormal climate variabilities, significantly shift the functioning of terrestrial ecosystems (Jentsch et al., 2011; Frank et al., 2015). There is an evidence that plant interactions (Filazzola et al., 2018), vegetation net primary productivity (Sun et al., 2016) and the resistant capacity of plant community (Dreesen et al., 2014) seemed to be more vulnerable to climate extremes than to average climatic conditions. Although effects of climate extremes on ecosystem processes and the resulting ecological consequences have been gradually tested (Wilcox et al., 2016), researches of climate extremes in terms of ecosystem functioning are far from perfection. An important reason is a hard quantification of drving impacts of climate extremes on the ecosystem dynamic. Moreover, mechanisms underlying responses of ecosystem processes to climate extremes, e.g. non-linear effects and threshold behaviors (Brotherton and Joyce, 2015), were not fully understood. Thus more concerns should be made on the ecological significance of climate extremes.

Until now, experimenters manipulated the magnitude of climatic factors like treatments of water reduction and open-top chamber warming, and assessed impacts of climate extremes on ecosystem functioning (Walter et al., 2011; Wang et al., 2012; Kreyling et al., 2017). However, they largely neglected potential interactions among climate extremes. Drought might offset effects of warming on aboveground biomass in a short time period. A combination of decreased rainfall and higher temperature was 
likely to exacerbate deficits in water budgets through an increased evaporation in temperate grasslands (Brotherton and Joyce, 2015). The impact of various climate extremes to ecosystem functions should be disentangled since the complex nature of ecosystem response to climate extremes is non-linear and non-additive.

Understanding ecosystem response to climate extremes can be advanced by incorporating approaches emphasizing the role of plant functional traits. Plant traits are measurable properties of an individual plant such as plant height, leaf area and root depth. The functional characteristics of traits are showed by their depiction on the fitness of plant species (Violle et al., 2007). Distributions of functional traits could indicate selection effects of abnormal climatic variabilities on plant communities. Larger rainfalls together with less rainy days stimulated the growth of deep-rooted plants as individual rainstorm led to a greater infiltration into deeper soil layers (Knapp et al., 2008; Tietjen, 2016). Plants responded to drought stress by structural adjustments such as decreased leaf area and increased root-shoot ratio (Teuling et al., 2006; Greenwood et al., 2017). Drought events were found to enhance the dispersal capacity of plant seeds (Zavalloni et al., 2009). Communities composed of long-lived plants might be resistant to individual extremes but be vulnerable to abrupt changes in climate regimes owing to a low turnover rate (Beier et al., 2012), since long-lived plants were more likely to experience cumulative influences of multiple extremes in the course of their lifespan.

Distributions or compositions of plant functional traits have been broadly found to be related to ecosystem functioning (Orwin et al., 2010; Zirbel et al., 2017). Plant functional traits and their associated trade-offs determined vegetation competitive abilities for light, water resources and nutrients (Kunstler et al., 2016). Trait-based approaches have been proposed incorporating into dynamic vegetation models for predictions of vegetation distribution and ecosystem functions (Webb et al., 2010; Soussana et al., 2012; van Bodegom et al., 2014). Functional trait compositions can advance our understanding of how ecosystem functioning responds to climate change (Helge et al., 2018). Compositional changes in functional traits led to a shift in biomass productions of the grassland community under conditions of increased warming events (White et al., 2000). Biomass productions of the herbaceous community were more determined by reproductive traits than competitive traits under drought stress (Dreesen et al., 2014). However, trait-based studies of climate extremes are constrained by lack of systematically experimental trait data and the highly non-linear plant response to climate extremes. This makes a quantitative assessment of extreme impacts on ecosystem functions virtually difficult. Therefore, the strength and the direction of links between functional trait patterns and ecosystem functions need to be evaluated based on simulating multiple scenarios of climate extremes.

In summary, most studies did not consider the full path from climate extremes via plant functional traits to ecosystem functioning. What extent climate extremes shape variations of plant functional traits or trait combinations is not well understood. Empirical investigations are the fundamental step to deal with the problem. However, owing to their limited complexity of spatio-temporal scales, we might draw an incomplete conclusion of climate extreme effects on patterns of functional traits. To fill out the knowledge gap, a full factorial modelling design, in which properties and interactions of individual climate extremes as well as all combinations of plant functional traits, is simulated to predict long term changes in ecosystem functioning. 
In the following, we present a stepwise research framework that includes a simulation of individual climate extremes and their interactions, modelling patterns of plant functional traits and their relationship with ecosystem functioning. Implementing this framework will pave the road towards benefiting practitioners in the aim of predicting ecosystem functioning. The methodology in the framework may play a greater role in regions susceptible to climate change, especially regions short of field data. Although we illustrate the research framework with reference to Qinghai-Tibetan alpine grassland ecosystems, we are confident that the framework is also feasible for studying effects of climate extremes on ecosystem functioning in a global scale.

\section{Construction of the framework}

Achieving an accurate prediction of ecosystem functioning toward future climate requires integrative knowledge from properties of climate extremes and trait-based studies as well as process-based dynamic vegetation models. Such approaches, however, have been so far missing. To achieve the above-mentioned goals, we put forward the following research questions to identify which plant functional traits are reliable indices for predictions of ecosystem functioning under conditions of climate extremes:

1) How should we simulate properties of climate extremes in the dynamic vegetation model?

2) What are patterns of functional traits under different scenarios of climate extremes?

3) How do functional trait patterns affect ecosystem functioning?

Here we briefly propose consecutive steps in a framework that describes how climate extremes and plant functional traits can be linked to achieve the ultimate goal. We thereafter elaborate these steps using an ongoing case study to illustrate the potential value of the approach.

\section{How should we do at first: the simulation of individual climate extremes and their interactions}

Assessing vegetation responses to precipitation and temperature should consider properties of climate extremes in reality. The consistent findings on precipitation patterns with increased extremity were not well covered by treatments applied in empirical experiments (Dwyer and O'Gorman, 2017). Similarly, current climate generators in ecosystem models did not fully capture abnormal variabilities of precipitation and temperature time-series recorded data (Reichstein et al., 2013). This may lead to an unrealistic simulation of driving effects on the vegetation dynamic. In addition, increased temperature resulting from long-term global warming was experimentally manipulated in short time periods. Rainfall extremes associated with increased temperature might be underestimated in terms of projections of future climate change (Allan and Soden, 2008). This urges us to simulate precipitation and temperature extremes in a more realistical way. It is necessary to at first identify types, the magnitude and the frequency of climate extremes based on studied regions. Designed scenarios of climate extreme should satisfy requirements that applied treatments are indeed 'abnormal' beyond current background variabilities of climate conditions over a time period. Otherwise we may run the risk of killing 'real' or maintain 'no-existed' plant types. 


\section{Link climate extremes with functional traits: Developing a process-based dynamic vegetation model}

To assess effects of climate extremes on the vegetation dynamic, fundamental ecosystem processes should be included in the model like water cycle, carbon cycle and vegetation demographical processes (Frank et al., 2015). Simulations of ecosystem processes refer to descriptions in the literature and these need to be adjusted and adapted to the studied system. Dynamic vegetation models used plant functional types depicted by suits of functional traits rather than specific species. This allowed for direct assessments of functional traits responding to climate changes (Mouillot et al., 2013). It was necessary to explicitly incorporate representative functional traits that were closely linked to vegetation dynamics under multiple climatic conditions (Fernandez-Going et al., 2012). Sensitivity analysis is an effective way to find out key trait parameters that should be carefully assigned values. If a sensitive parameter is uncertain, this uncertainty should be conducted through model simulations to establish a full range of potential outcomes. Trait parameterization is a crucial step to gain full confidence of vegetation simulations which should be based on empirical data e.g. the corresponding relationship between simulated trait parameters and measured traits in reality.

\section{Patterns of functional traits and their relationship with ecosystem functioning under different scenarios of climate extremes}

A knowledge gap that cannot be filled by experimental data is that effects of climate extremes on ecosystem functioning are not additive. Modelling ecosystem behaviors after climate extremes requires in depth understanding of patterns at the level of plant functional traits. Patterns of functional traits may aid us to identify thresholds of community responses to individual climate extremes. In case pulses exerted by climate extremes went beyond thresholds of community resistance or tolerance, they would cause dramatic changes in ecosystem functioning (Diez et al., 2012). Plant communities adapted to dynamic environmental conditions and with a higher diversity of functional traits might have advantages in the recovery from climate extremes (Brotherton and Joyce, 2015). The relationship between patterns of functional traits and ecosystem functioning should be assessed in a full factorial design under multiple scenarios of climate extremes. We should be aware that specific trait combinations determine one function or single functional trait plays different roles for various function indices.

\section{A case study in Qinghai-Tibetan alpine grasslands}

We exemplify the framework using an ongoing case study with a focus on QinghaiTibetan alpine grasslands. Climate extremes largely drove ecosystem functioning in cold biomes with high altitudes (Marcolla et al., 2011; Wipf et al., 2013). The unique geographical and climatic conditions in Qinghai-Tibetan Plateau determine processes of water and carbon cycle in eastern Asia (Yao et al., 2012). In addition, most regions are characterized by arid or semi-arid biomes. Low temperature and water shortage were both limiting factors for resource acquisition of alpine plants. Demographical rates closely linked with traits of alpine plants (Blonder et al., 2018). Alpine plants were generally long-lived. Vegetation processes might work at a slower rate than warmer areas (Gottfried et al., 2012). Average plant height usually declined with an increased altitude (Butterfield and Suding, 2013). Alpine plants often developed opportunistic 
traits in response to late snowmelt due to altitudinal constraints (Almeida et al., 2013). Functional trait diversity of alpine plants can regulate the response of vegetation productivity to regional climate change (Wu et al., 2016). Measured data of functional traits in most regions of Qinghai-Tibetan Plateau were much limited, characterized by a short time scale and lack of the comparability among regions. Thus, simulating effects of climate extremes on ecosystem functioning through plant functional traits may permit us to understand the underlying mechanisms of alpine ecosystem dynamic. We should have an awareness that part of areas in Qinghai-Tibetan Plateau already locate under socalled climate extreme conditions (e.g. very low temperature or covered by snow all year around), where plant functional traits are evolutionary outcomes of their environmental conditions. More extremes of climate conditions probably lead to weak or no changes in ecosystem functioning. To achieve the goal of accurately predicting ecosystem functioning, our approach integrates a database of plant functional traits and community properties in the Haibei station (one of typical experimental stations in Qinghai-Tibetan Plateau) with a process-based dynamic vegetation model. In the following we demonstrate the application of every consecutive step, that is, how we perform the framework in Haibei alpine grasslands to address our research questions (Fig. 1).
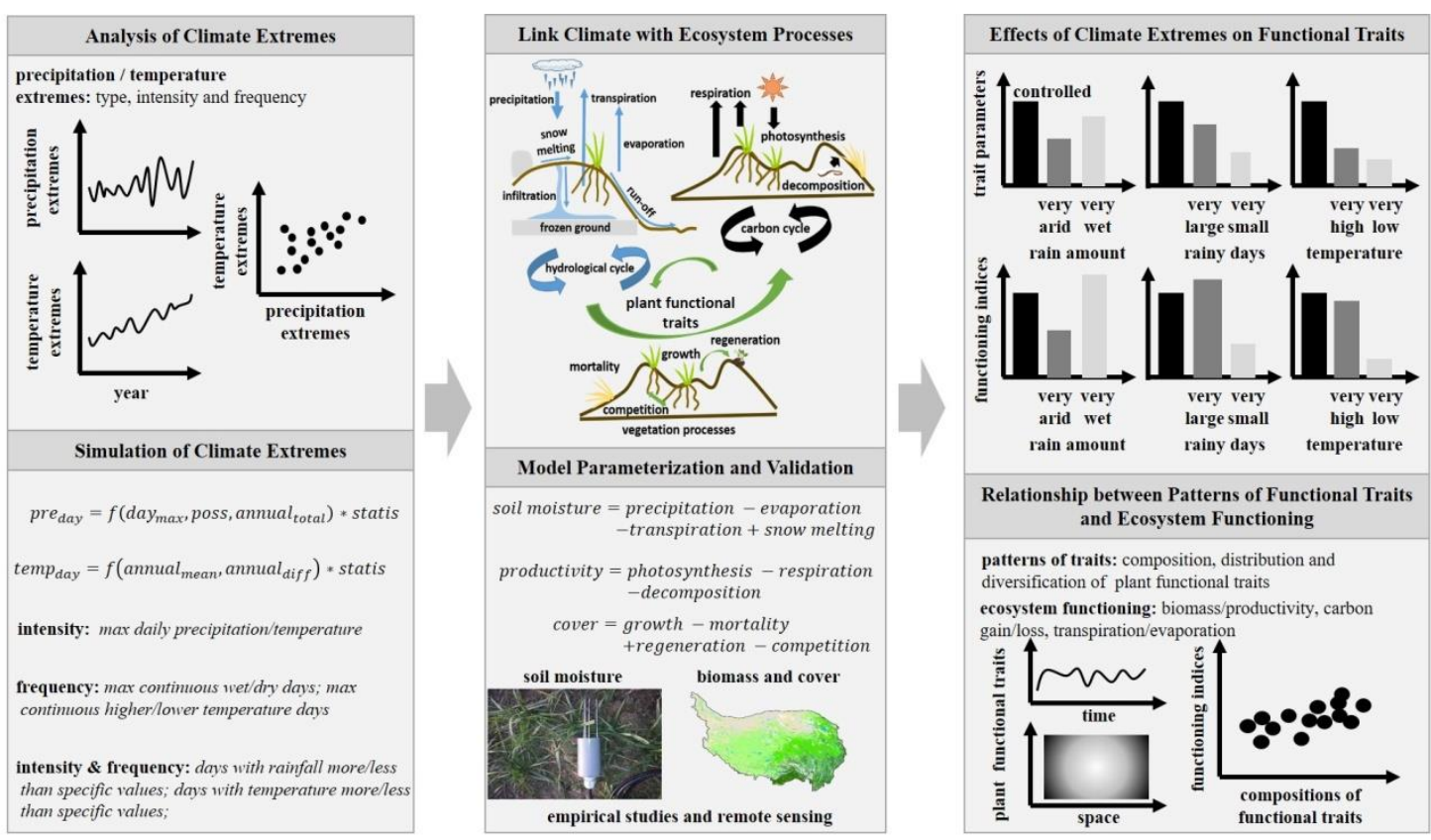

Figure 1. Every steps performed in our case study for evaluating effects of climate extremes on functional traits patterns and their relationship with ecosystem functioning. The left panel: 1) we analyze temporal variations of precipitation and temperature extremes as well as interactions between individual extreme indices. 2) We incorporate properties of extreme indices into the climate generator to better simulate the vegetation dynamic in the model. The middle panel: 1) We simulate ecosystem processes related to carbon cycle, water cycle and vegetation demography. These processes interconnect and are adjusted by plant functional traits. 2) We calibrate and validate the model based on site-specific measured data at the Haibei station in Qinghai Province. The right panel: 1) We compare patterns of functional traits between the baseline scenario and various climate extreme scenarios; 2) $W$ will evaluate the relationship between patterns of functional traits and ecosystem functioning under respective climatic scenarios 


\section{Simulations of climate extremes}

Properties of individual climate extremes should be depicted based on long term climate data. We obtained 56 years (1960 - 2015) climate data from two weather stations nearest to the Haibei station. Thereafter we analyzed the temporal variations of individual climate extreme indices recommended by Expert Team on Climate Change Detection, Monitoring and Indices (Alexander et al., 2006). We selected several representative extreme indices based on ecosystem characteristics of Qinghai-Tibetan Plateau. These extreme properties are incorporated into the climate generator (Table 1). To evaluate future threats of respective climate extremes, outcomes of the multiple extreme scenarios are compared with the cumulative outcomes of the single extreme scenario. Based on regional climatic characteristics and the temporal trend of historical data, we conduct an increased extremity for each scenario (a change of $10 \%$ and 20\%) and covariations of individual climate extremes.

Table 1. Simulating properties of climate extremes in the dynamic vegetation model

\begin{tabular}{|c|c|c|}
\hline Climate factors & Types & Dimensions \\
\hline Precipitation & $\begin{array}{l}\text { Max continuous dry/wet days in grow seasons } \\
\text { Increased precipitation intensity } \\
\text { Increased inter-annual variability } \\
\text { Rainy days larger than specific values in grow seasons } \\
\text { Max snowy days and snowfall larger than } 2 \mathrm{~mm}\end{array}$ & $\begin{array}{l}\text { Frequency } \\
\text { Intensity/Frequency } \\
\text { Intensity/Frequency } \\
\text { Intensity/Frequency } \\
\text { Intensity/Frequency }\end{array}$ \\
\hline Temperature & $\begin{array}{c}\text { Increased annual temperature } \\
\text { Max/Min daily temperature deviations } \\
\text { Max continuous higher temperature days in grow seasons } \\
\text { Days of temperature higher than specific values in and around } \\
\text { grow seasons }\end{array}$ & $\begin{array}{c}\text { Intensity } \\
\text { Intensity } \\
\text { Intensity/Frequency } \\
\text { Intensity/Frequency }\end{array}$ \\
\hline
\end{tabular}

\section{Localizing a dynamic vegetation model in Qinghai-Tibetan alpine grasslands}

There were so far few dynamic vegetation models applied in alpine grassland ecosystems. Most models used statistical or remote sensing ways since the parameterization of a dynamic vegetation model is a much difficult task owing to lack of systematically measured soil and plant data. The elements considered in the model include the vegetation dynamic, plant functional traits, soil properties, hydrological and carbon cycling processes. We simulate different scenarios of climate extremes and analyze the influences of extremes on ecosystem elements. In the model, we should be careful of the specificity of alpine ecosystem processes and their potential interactions. The alpine grasslands at high altitudes are characterized by a low temperature over a long time period, especially in winters the evaporation flux is quite low. Low temperature also leads to a slow decomposition rate of organic carbon. Thus the soil stock might be deemed as a carbon sink, which indirectly benefits vegetation growth. In addition, effects of snow cover on the vegetation dynamic were largely ignored in most vegetation models. We localize the dynamic vegetation model adapted to QinghaiTibetan alpine grasslands by calculating all relevant ecosystem processes with a reference to a process-based dynamic vegetation model (Tietjen et al., 2009, 2010; Guo et al., 2016, 2018). The model is characterized by explicit ecosystem processes and spatio-temporal scales. 


\section{Model overview}

We simulate the landscape based on geographical characteristics, e.g. the elevation, the slope and soil conditions, of Haibei station. The simulated landscape is separated into grid cells (each cell: 20 by $20 \mathrm{~m}^{2}$ ) and different layers per cell. We assume a homogeneity of soil properties within the size of grid cells. The depth of soil layers is determined by site-specific soil heterogeneity. The simulated soil depth is not more than $1 \mathrm{~m}$ as we do not consider the ecosystem dynamic in permafrost layers. Each layer is depicted by a combination of soil parameters (Guo et al., 2018). These parameters are calibrated by measured soil physic-chemical and hydraulic indices. Representative plant functional types (PFTs) are selected based on local dominant and constructive species. Proxies indicating ecosystem functioning include above- and belowground plant biomass, litter and dead biomass, carbon storage in plant and soil, plant transpiration and soil evaporation. In order to track the changes in these functions, water, carbon cycle and vegetation processes are calculated for each grid cell. We briefly describe these interrelated processes as follows.

\section{Vegetation processes and the parameterization of plant functional traits}

Vegetation processes capture the entire life cycle and describe demographical characteristics of herbaceous plants distributing over the landscape. Main processes include photosynthetic growth, seed dispersal/establishment, mortality and grazing by livestock. The competition among PFTs is explicitly simulated in terms of water, light and space. Vegetation processes dependent on specific plant functional traits (Table 2) are driven by available soil water and soil temperature.

Table 2. Main vegetation processes and trait parameters in the model

\begin{tabular}{|c|c|c|c|}
\hline $\begin{array}{l}\text { Vegetation } \\
\text { processes }\end{array}$ & Influencing factors & Measured traits & Trait parameters \\
\hline Growth & $\begin{array}{l}\text { Precipitation } \\
\text { Temperature }\end{array}$ & $\begin{array}{c}\text { Biomass calculation in leaf, shoot and } \\
\text { root } \\
\text { Allocation of water in leaf, shoot and } \\
\text { root } \\
\text { Allocation of organic carbon in leaf, } \\
\text { shoot and root }\end{array}$ & $\begin{array}{l}\text { Growth rate } \\
\text { Water uptake and } \\
\text { transmission rate } \\
\text { Carbon uptake and } \\
\text { transmission rate }\end{array}$ \\
\hline Mortality & $\begin{array}{l}\text { Precipitation } \\
\text { Temperature }\end{array}$ & $\begin{array}{c}\text { Biomass reduction in leaf, shoot and } \\
\text { root } \\
\text { The decreased number of plant } \\
\text { species or individuals }\end{array}$ & Mortality rate \\
\hline Reproduction & $\begin{array}{l}\text { Precipitation } \\
\text { Temperature }\end{array}$ & $\begin{array}{c}\text { The number and the size of seeds } \\
\text { The distance between adult and child } \\
\text { plants } \\
\text { The number of child plants }\end{array}$ & $\begin{array}{c}\text { Dispersal rate } \\
\text { Range of distance } \\
\text { Establishment rate }\end{array}$ \\
\hline Competition & $\begin{array}{l}\text { Precipitation } \\
\text { Temperature }\end{array}$ & $\begin{array}{c}\text { Vegetation cover or leaf area index } \\
\text { Distribution of leaf and root }\end{array}$ & $\begin{array}{c}\text { Competition for space } \\
\text { Competition for water and } \\
\text { carbon }\end{array}$ \\
\hline
\end{tabular}

Equations of vegetation processes are mainly constructed through vegetation cover and biomass (Tietjen et al., 2010; Guo et al., 2016). Trait combinations of plant functional types are parameterized by local plant species based on their light and water capture strategy, growth form, leaf size, plant height, rooting depth. The trait parameterization mainly relies on the investigation of dominant and constructive species 
in local areas. Moreover functional traits are assigned values partly based on reference data of Qinghai-Tibetan ecosystems (He et al., 2006; Qi et al., 2014; Wang et al., 2014). The sensitivity of trait variations has to be assessed through single trait change or joint trait changes. The simulated plant community is composed of different plant functional types depicted by sound trait combinations including covariations (e.g., growth rate \& resistance to grazing; seed size \& seed number; leaf area \& plant height). There existed diverse trade-offs among traits in Qinghai alpine ecosystems (Du and Qi, 2010). The diversification of plant functional types in the model is constrained by proper values (maximum, minimum and average) of individual functional traits. We assume a completely balanced state of trade-offs within a newly constructed PFT. That is, the number of traits, whose values locate between average and maximum, equals the number of traits with values assigned between minimum and average. To test whether we define the 'right' functional types that match the real plant community, we should repeatedly and randomly conduct various trait combinations of plant functional types in long term simulations. Moreover, the local richness of plant species should be investigated to evaluate the simulated number of PFTs in grid cells.

\section{Hydrological and carbon processes}

Hydrological processes revolve round the calculation of soil moisture for different layers across all grid cells. Relevant processes include infiltration, runoff, evaporation and transpiration. These processes depend on site-specific soil texture, topography, weather and community properties. A challenge during this procedure is that water processes act on different temporal and spatial scales. This can be solved using a hierarchical setting, which calculated processes in separated sub-modules running on various spatio-temporal scales (Tietjen et al., 2009). Carbon storage and fluxes are assessed for each grid cell dependent on soil properties, soil moisture, vegetation cover and above- and belowground biomass. Main processes include photosynthesis, respiration, litter decomposition, biomass degradation. The parameterization and equations of water and carbon processes refer to previous empirical or modelling studies (Gu et al., 2008; Tan et al., 2010; Yan et al., 2015). Coupled interactions between water and carbon processes are very crucial for vegetation dynamic and ecosystem functioning. Carbon cycle was verified to be linked with nitrogen cycle in Qinghai-Tibetan Plateau (Lee et al., 2013). However, the model is currently not considering any nutrient cycling processes. To test the suitability of every ecosystem process in the selected areas, the model should be run under the very same climatic conditions. In addition, all indices that are employed to quantify ecosystem functions should be validated. Specifically, simulated soil moisture, community cover and biomass, plant and soil carbon content are compared to measured dynamics of the Haibei station.

\section{Patterns of functional traits and their relationship with ecosystem functioning}

In the following, we implement simulation experiments under various scenarios of climate extremes to assess how future climate extremes shape patterns of functional traits and the associated ecosystem functioning in alpine grasslands. Ecosystem functions like biomass, fluxes of resource cycling are evaluated via absolute as well as proxy measurements. We firstly assess the effects of climate extremes on ecosystem functioning with a limited number of plant functional types. To test the separated and interactive effects of individual climate extremes, all other extreme properties are kept 
on a constant level. That is, all climate extremes should be run separately and in different combinations in a full factorial design. Then we diversify trait combinations and observe this effect. Combinations of functional traits are detected that are sensitive to specific climate extremes. More importantly we can know which plant functional traits are reliable indicators of ecosystem functions under different scenarios of climate extremes. The relationship between patterns of functional traits and ecosystem functioning should be assessed across all treatments of climate extremes. Our model approach clearly demonstrates site-specific characteristics of the Haibei station such as geographical and community properties. Through the application of a case study like this, we can propose specific plant functional traits or trait combinations that indicate abnormal variabilities in climatic conditions and thus strengthen assessments of ecosystem functioning. In a follow-up analysis, we can advance our knowledge on the Qinghai-Tibetan alpine ecosystems in general. E.g. in case we test whether the framework works in other Qinghai-Tibetan Plateau sites, we could modify soil, weather conditions and vegetation type if necessary while keeping ecosystem processes consistent. Model experiments can be performed for different Qinghai-Tibetan areas after the model has been calibrated and validated for respective sites. This can verify whether functional traits and trait combinations respond to climate extremes as well relate with ecosystem functioning is site specific. Future work could also consider other global change factors (grazing or nitrogen deposition) and trade-offs among ecosystem functions that deserve great attentions for the land restoration.

\section{Conclusion}

To our knowledge, there are few mechanistic approaches that can assess long-term vegetation dynamic and ecosystem functioning through patterns of functional traits under impacts of climate extremes. We believe that the proposed framework fill the gaps and therefore closely link abiotic climatic factors with biotic agents like alpine vegetation. We use the response of plant functional traits to climate extremes to predict ecosystem functioning since variations of ecosystem functions are sometimes difficultly captured by changes in climatic conditions. Through this endeavor, the relationship between patterns of functional traits and ecosystem functioning can be better understood under different scenarios of climate extremes. Achieving the goal of a precise prediction of ecosystem functioning under complex climatic conditions needs an integration of different research approaches. Our proposed framework provides a promising scheme for a scientific assessment of ecosystem functioning in Qinghai-Tibetan alpine ecosystems lack of long term measured data.

Acknowledgements. This work was supported by China Postdoctoral Science Foundation (2018M641072). We thank anonymous reviewers for very constructive suggestions on the original namuscript.

\section{REFERENCES}

[1] Alexander, L. V., Zhang, X., Peterson, T. C., Caesar, J., Gleason, B., Tank, A. M. G. K., Haylock, M., Collins, D., Trewin, B., Rahimzadeh, F., Tagipour, A., Kumar, K. R., Revadekar, J., Griffiths, G., Vincent, L., Stephenson, D. B., Burn, J., Aguilar, E., Brunet, M., Taylor, M., New, M., Zhai, P., Rusticucci, M., Vazquez-Aguirre, J. L. (2006): Global 
observed changes in daily climate extremes of temperature and precipitation. - Journal of Geophysical Research-Atmospheres 111: 1-22. doi: 10.1029/2005jd006290.

[2] Allan, R. P., Soden, B. J. (2008): Atmospheric warming and the amplification of precipitation extremes. - Science 321: 1481-1484. doi:10.1126/science.1160787.

[3] Almeida, J. P., Montúfar, R., Anthelme, F. (2013): Patterns and origin of intraspecific functional variability in a tropical alpine species along an altitudinal gradient. - Plant Ecology \& Diversity 6: 423-433. doi:10.1080/17550874.2012.702137.

[4] Beier, C., Beierkuhnlein, C., Wohlgemuth, T., Penuelas, J., Emmett, B., Korner, C., de Boeck, H. J., Christensen, J. H., Leuzinger, S., Janssens, I. A., Hansen, K. (2012): Precipitation manipulation experiments - challenges and recommendations for the future. - Ecology letters 15: 899-911. doi:10.1111/j.1461-0248.2012.01793.x.

[5] Blonder, B., Kapas Rozalia, E., Dalton Rebecca, M., Graae Bente, J., Heiling Jacob, M., Opedal Øystein, H. (2018): Microenvironment and functional-trait context dependence predict alpine plant community dynamics. - Journal of Ecology 106: 1323-1337. doi:10.1111/1365-2745.12973.

[6] Brotherton, S. J., Joyce, C. B. (2015): Extreme climate events and wet grasslands: plant traits for ecological resilience. - Hydrobiologia 750: 229-243. doi:10.1007/s10750-0142129-5.

[7] Bruelheide, H., Dengler, J., Purschke, O., Lenoir, J., Jimenez-Alfaro, B., Hennekens, S. M., Botta-Dukat, Z., Chytry, M., Field, R., Jansen, F., Kattge, J., Pillar, V. D., Schrodt, F., Mahecha, M. D., Peet, R. K., Sandel, B., van Bodegom, P., Altman, J., AlvarezDavila, E., Khan, M. A. S. A., Attorre, F., Aubin, I., Baraloto, C., Barroso, J. G., Bauters, M., Bergmeier, E., Biurrun, I., Bjorkman, A. D., Blonder, B., Carni, A., Cayuela, L., Cerny, T., Cornelissen, J. H. C., Craven, D., Dainese, M., Derroire, G., De Sanctis, M., Diaz, S., Dolezal, J., Farfan-Rios, W., Feldpausch, T. R., Fenton, N. J., Garnier, E., Guerin, G. R., Gutierrez, A. G., Haider, S., Hattab, T., Henry, G., Herault, B., Higuchi, P., Holzel, N., Homeier, J., Jentsch, A., Jurgens, N., Kacki, Z., Karger, D. N., Kessler, M., Kleyer, M., Knollova, I., Korolyuk, A. Y., Kuhn, I., Laughlin, D. C., Lens, F., Loos, J., Louault, F., Lyubenova, M. I., Malhi, Y., Marceno, C., Mencuccini, M., Muller, J. V., Munzinger, J., Myers-Smith, I. H., Neill, D. A., Niinemets, U., Orwin, K. H., Ozinga, W. A., Penuelas, J., Perez-Haase, A., Petrik, P., Phillips, O. L., Partel, M., Reich, P. B., Romermann, C., Rodrigues, A. V., Sabatini, F. M., Sardans, J., Schmidt, M., Seidler, G., Espejo, J. E. S., Silveira, M., Smyth, A., Sporbert, M., Svenning, J. C., Tang, Z. Y., Thomas, R., Tsiripidis, I., Vassilev, K., Violle, C., Virtanen, R., Weiher, E., Welk, E., Wesche, K., Winter, M., Wirth, C., Jandt, U. (2018): Global trait-environment relationships of plant communities. - Nature Ecology \& Evolution 2: 1906-1917. doi:10.1038/s41559-018-0699-8.

[8] Butterfield, B. J., Suding, K. N. (2013): Single-trait functional indices outperform multitrait indices in linking environmental gradients and ecosystem services in a complex landscape. - Journal of Ecology 101: 9-17. doi:10.1111/1365-2745.12013.

[9] Diez, J. M., D'Antonio, C. M., Dukes, J. S., Grosholz, E. D., Olden, J. D., Sorte, C. J. B., Blumenthal, D. M., Bradley, B. A., Early, R., Ibanez, I., Jones, S. J., Lawler, J. J., Miller, L. P. (2012): Will extreme climatic events facilitate biological invasions? - Frontiers in Ecology and the Environment 10: 249-257. doi:10.1890/110137.

[10] Dreesen, F. E., De Boeck, H. J., Janssens, I. A., Nijs, I. (2014): Do successive climate extremes weaken the resistance of plant communities? An experimental study using plant assemblages. - Biogeosciences 11: 109-121. doi:10.5194/bg-11-109-2014.

[11] Du, G. Z., Qi, W. (2010): Trade-offs between flowering time, plant height, and seed size within and across 11 communities of a QingHai-Tibetan flora. - Plant Ecology 209: 321333. doi:10.1007/s11258-010-9763-4.

[12] Dwyer, J. G., O'Gorman, P. A. (2017): Changing duration and spatial extent of midlatitude precipitation extremes across different climates. - Geophysical Research Letters 44: 5863-5871. doi: 10.1002/2017g1072855. 
[13] Fernandez-Going, B. M., Anacker, B. L., Harrison, S. P. (2012): Temporal variability in California grasslands: Soil type and species functional traits mediate response to precipitation. - Ecology 93: 2104-2114. doi:10.1890/11-2003.1.

[14] Filazzola, A., Liczner, A. R., Westphal, M., Lortie, C. J. (2018): The effect of consumer pressure and abiotic stress on positive plant interactions are mediated by extreme climatic events. - New Phytologist 217: 140-150. doi: 10.1111/nph.14778.

[15] Frank, D., Reichstein, M., Bahn, M., Thonicke, K., Frank, D., Mahecha, M. D., Smith, P., Van der Velde, M., Vicca, S., Babst, F., Beer, C., Buchmann, N., Canadell, J. G., Ciais, P., Cramer, W., Ibrom, A., Miglietta, F., Poulter, B., Rammig, A., Seneviratne, S. I., Walz, A., Wattenbach, M., Zavala, M. A., Zscheischler, J. (2015): Effects of climate extremes on the terrestrial carbon cycle: concepts, processes and potential future impacts. - Global Change Biology 21: 2861-2880. doi:10.1111/gcb.12916.

[16] Gottfried, M., Pauli, H., Futschik, A., Akhalkatsi, M., Barancok, P., Alonso, J. L. B., Coldea, G., Dick, J., Erschbamer, B., Calzado, M. R. F., Kazakis, G., Krajci, J., Larsson, P., Mallaun, M., Michelsen, O., Moiseev, D., Moiseev, P., Molau, U., Merzouki, A., Nagy, L., Nakhutsrishvili, G., Pedersen, B., Pelino, G., Puscas, M., Rossi, G., Stanisci, A., Theurillat, J. P., Tomaselli, M., Villar, L., Vittoz, P., Vogiatzakis, I., Grabherr, G. (2012): Continent-wide response of mountain vegetation to climate change. - Nature Climate Change 2: 111-115. doi:10.1038/Nclimate1329.

[17] Greenwood, S., Ruiz-Benito, P., Martínez-Vilalta, J., Lloret, F., Kitzberger, T., Allen, C. D., Fensham, R., Laughlin, D. C., Kattge, J., Bönisch, G., Kraft, N. J. B., Jump, A. S. (2017): Tree mortality across biomes is promoted by drought intensity, lower wood density and higher specific leaf area. - Ecology letters 20: 539-553. doi:10.1111/ele.12748.

[18] Gu, S., Tang, Y., Cui, X., Du, M., Zhao, L., Li, Y., Xu, S., Zhou, H., Kato, T., Qi, P., Zhao, X. (2008): Characterizing evapotranspiration over a meadow ecosystem on the Qinghai-Tibetan Plateau. - Journal of Geophysical Research 113. doi:10.1029/2007jd009173.

[19] Guo, T., Lohmann, D., Ratzmann, G., Tietjen, B. (2016): Response of semi-arid savanna vegetation composition towards grazing along a precipitation gradient-The effect of including plant heterogeneity into an ecohydrological savanna model. - Ecological Modelling 325: 47-56. doi:10.1016/j.ecolmodel.2016.01.004.

[20] Guo, T., Weise, H., Fiedler, S., Lohmann, D., Tietjen, B. (2018): The role of landscape heterogeneity in regulating plant functional diversity under different precipitation and grazing regimes in semi-arid savannas. - Ecological Modelling 379: 1-9. doi:10.1016/j.ecolmodel.2018.04.009.

[21] He, J. S., Wang, Z. H., Wang, X. P., Schmid, B., Zuo, W. Y., Zhou, M., Zheng, C. Y., Wang, M. F., Fang, J. Y. (2006): A test of the generality of leaf trait relationships on the Tibetan Plateau. - New Phytologist 170: 835-848. doi:10.1111/j.14698137.2006.01704.x.

[22] Jentsch, A., Kreyling, J., Elmer, M., Gellesch, E., Glaser, B., Grant, K., Hein, R., Lara, M., Mirzae, H., Nadler, S. E., Nagy, L., Otieno, D., Pritsch, K., Rascher, U., Schadler, M., Schloter, M., Singh, B. K., Stadler, J., Walter, J., Wellstein, C., Wollecke, J., Beierkuhnlein, C. (2011): Climate extremes initiate ecosystem-regulating functions while maintaining productivity. - Journal of Ecology 99: 689-702. doi:10.1111/j.13652745.2011.01817.x.

[23] Knapp, A. K., Beier, C., Briske, D. D., Classen, A. T., Luo, Y., Reichstein, M., Smith, M. D., Smith, S. D., Bell, J. E., Fay, P. A., Heisler, J. L., Leavitt, S. W., Sherry, R., Smith, B., Weng, E. (2008): Consequences of More Extreme Precipitation Regimes for Terrestrial Ecosystems. - Bioscience 58: 811-821. doi:10.1641/B580908.

[24] Kreyling, J., Dengler, J., Walter, J., Velev, N., Ugurlu, E., Sopotlieva, D., Ransijn, J., Picon-Cochard, C., Nijs, I., Hernandez, P., Guler, B., von Gillhaussen, P., De Boeck, H. J., Bloor, J. M. G., Berwaers, S., Beierkuhnlein, C., Arfin Khan, M. A. S., Apostolova, I., 
Altan, Y., Zeiter, M., Wellstein, C., Sternberg, M., Stampfli, A., Campetella, G., Bartha, S., Bahn, M., Jentsch, A. (2017): Species richness effects on grassland recovery from drought depend on community productivity in a multisite experiment. - Ecology Letters 20: 1405-1413. doi: 10.1111/ele.12848.

[25] Kunstler, G., Falster, D., Coomes, D. A., Hui, F., Kooyman, R. M., Laughlin, D. C., Poorter, L., Vanderwel, M., Vieilledent, G., Wright, S. J., Aiba, M., Baraloto, C., Caspersen, J., Cornelissen, J. H. C., Gourlet-Fleury, S., Hanewinkel, M., Herault, B., Kattge, J., Kurokawa, H., Onoda, Y., Penuelas, J., Poorter, H., Uriarte, M., Richardson, S., Ruiz-Benito, P., Sun, I. F., Stahl, G., Swenson, N. G., Thompson, J., Westerlund, B., Wirth, C., Zavala, M. A., Zeng, H. C., Zimmerman, J. K., Zimmermann, N. E., Westoby, M. (2016): Plant functional traits have globally consistent effects on competition. Nature 529: 204-207. doi:10.1038/nature16476.

[26] Lee, Y. H., Lim, H. J., Ichii, K., Li, Y. N. (2013): Evaluation of the Community Land Model 3.5 with carbon and nitrogen cycles (CLM3.5CN) at a Tibetan grassland site. Asia-Pacific Journal of Atmospheric Sciences 49: 561-570. doi:10.1007/s13143-0130050-x.

[27] Marcolla, B., Cescatti, A., Manca, G., Zorer, R., Cavagna, M., Fiora, A., Gianelle, D., Rodeghiero, M., Sottocornola, M., Zampedri, R. (2011): Climatic controls and ecosystem responses drive the inter-annual variability of the net ecosystem exchange of an alpine meadow. - Agricultural and Forest Meteorology 151: 1233-1243. doi:10.1016/j.agrformet.2011.04.015.

[28] Mouillot, D., Graham, N. A. J., Villeger, S., Mason, N. W. H., Bellwood, D. R. (2013): A functional approach reveals community responses to disturbances. - Trends in Ecology \& Evolution 28: 167-177. doi:10.1016/j.tree.2012.10.004.

[29] Orwin, K. H., Buckland, S. M., Johnson, D., Turner, B. L., Smart, S., Oakley, S., Bardgett, R. D. (2010): Linkages of plant traits to soil properties and the functioning of temperate grassland. - Journal of Ecology 98: 1074-1083. doi:10.1111/j.13652745.2010.01679.x.

[30] Qi, W., Bu, H. Y., Liu, K., Li, W. J., Knops, J. M. H., Wang, J. H., Li, W. L., Du, G. Z. (2014): Biological traits are correlated with elevational distribution range of eastern Tibetan herbaceous species. - Plant Ecology 215: 1187-1198. doi:10.1007/s11258-0140377-0.

[31] Reichstein, M., Bahn, M., Ciais, P., Frank, D., Mahecha, M. D., Seneviratne, S. I., Zscheischler, J., Beer, C., Buchmann, N., Frank, D. C., Papale, D., Rammig, A., Smith, P., Thonicke, K., van der Velde, M., Vicca, S., Walz, A., Wattenbach, M. (2013): Climate extremes and the carbon cycle. - Nature 500: 287-295. doi:10.1038/nature12350.

[32] Soussana, J. F., Maire, V., Gross, N., Bachelet, B., Pages, L., Martin, R., Hill, D., Wirth, C. (2012): Gemini: A grassland model simulating the role of plant traits for community dynamics and ecosystem functioning. Parameterization and evaluation. - Ecological Modelling 231: 134-145. doi: 10.1016/j.ecolmodel.2012.02.002.

[33] Sun, G., Wang, Z. Y., Zhu-Barker, X., Zhang, N. N., Wu, N., Liu, L., Lei, Y. B. (2016): Biotic and abiotic controls in determining exceedingly variable responses of ecosystem functions to extreme seasonal precipitation in a mesophytic alpine grassland. Agricultural Forest Meteorology 228: 180-190. doi: 10.1016/j.agrformet.2016.07.010.

[34] Tan, K., Ciais, P., Piao, S. L., Wu, X. P., Tang, Y. H., Vuichard, N., Liang, S., Fang, J. Y. (2010): Application of the ORCHIDEE global vegetation model to evaluate biomass and soil carbon stocks of Qinghai-Tibetan grasslands. - Global Biogeochemical Cycles 24. doi:10.1029/2009gb003530.

[35] Teuling, A. J., Uijlenhoet, R., Hupet, F., Troch, P. A. (2006): Impact of plant water uptake strategy on soil moisture and evapotranspiration dynamics during drydown. Geophysical Research Letters 33. doi:10.1029/2005gl025019. 
[36] Tietjen, B., Zehe, E., Jeltsch, F. (2009): Simulating plant water availability in dry lands under climate change: A generic model of two soil layers. - Water Resources Research 45: 1-14. doi:10.1029/2007wr006589.

[37] Tietjen, B., Jeltsch, F., Zehe, E., Classen, N., Groengroeft, A., Schiffers, K., Oldeland, J. (2010): Effects of climate change on the coupled dynamics of water and vegetation in drylands. - Ecohydrology 3: 226-237. doi:10.1002/eco.70.

[38] Tietjen, B. (2016): Same rainfall amount different vegetation-How environmental conditions and their interactions influence savanna dynamics. - Ecological Modelling 326: 13-22. doi: 10.1016/j.ecolmodel.2015.06.013.

[39] van Bodegom, P. M., Douma, J. C., Verheijen, L. M. (2014): A fully traits-based approach to modeling global vegetation distribution. - Proceedings of the National Academy of Sciences of the United States of America 111: 13733-13738. doi:10.1073/pnas.1304551110.

[40] Violle, C., Navas, M.-L., Vile, D., Kazakou, E., Fortunel, C., Hummel, I., Garnier, E. (2007): Let the concept of trait be functional! - Oikos 116: 882-892. doi:10.1111/j.00301299.2007.15559.x.

[41] Walter, J., Nagy, L., Hein, R., Rascher, U., Beierkuhnlein, C., Willner, E., Jentsch, A. (2011): Do plants remember drought? Hints towards a drought-memory in grasses. Environmental and Experimental Botany 71: 34-40. doi:10.1016/j.envexpbot.2010.10.020.

[42] Wang, X., Nakatsubo, T., Nakane, K. (2012): Impacts of elevated $\mathrm{CO}_{2}$ and temperature on soil respiration in warm temperate evergreen Quercus glauca stands: an open-top chamber experiment. - Ecological Research 27: 595-602. doi:10.1007/s11284-012-0932$\mathrm{x}$.

[43] Wang, Y. J., Wang, J. J., Lai, L. M., Jiang, L. H., Zhuang, P., Zhang, L. H., Zheng, Y. R., Baskin, J. M., Baskin, C. C. (2014): Geographic variation in seed traits within and among forty-two species of Rhododendron (Ericaceae) on the Tibetan plateau: relationships with altitude, habitat, plant height, and phylogeny. - Ecology and Evolution 4: 1913-1923. doi:10.1002/ece3.1067.

[44] Webb, C. T., Hoeting, J. A., Ames, G. M., Pyne, M. I., LeRoy Poff, N. (2010): A structured and dynamic framework to advance traits-based theory and prediction in ecology. - Ecology letters 13: 267-283. doi:10.1111/j.1461-0248.2010.01444.x.

[45] White, T. A., Campbell, B. D., Kemp, P. D., Hunt, C. L. (2000): Sensitivity of three grassland communities to simulated extreme temperature and rainfall events. - Global Change Biology 6: 671-684. doi:10.1046/j.1365-2486.2000.00344.x.

[46] Wilcox, K. R., Blair, J. M., Knapp, A. K. (2016): Stability of grassland soil C and N pools despite 25 years of an extreme climatic and disturbance regime. - Journal of Geophysical Research: Biogeosciences 121: 1934-1945. doi: 10.1002/2016JG003370.

[47] Wipf, S., Gottfried, M., Nagy, L. (2013): Climate change and extreme events - their impacts on alpine and arctic ecosystem structure and function. - Plant Ecology \& Diversity 6: 303-306. doi:10.1080/17550874.2013.819533.

[48] Wu, J. S., Wurst, S., Zhang, X. Z. (2016): Plant functional trait diversity regulates the nonlinear response of productivity to regional climate change in Tibetan alpine grasslands. - Scientific Reports 6: 1-10. doi: 10.1038/srep35649.

[49] Yan, L., Zhou, G. S., Wang, Y. H., Hu, T. Y., Sui, X. H. (2015): The spatial and temporal dynamics of carbon budget in the alpine grasslands on the Qinghai-Tibetan Plateau using the Terrestrial Ecosystem Model. - Journal of Cleaner Production 107: 195-201. doi:10.1016/j.jclepro.2015.04.140.

[50] Yao, T. D., Thompson, L., Yang, W., Yu, W. S., Gao, Y., Guo, X. J., Yang, X. X., Duan, K. Q., Zhao, H. B., Xu, B. Q., Pu, J. C., Lu, A. X., Xiang, Y., Kattel, D. B., Joswiak, D. (2012): Different glacier status with atmospheric circulations in Tibetan Plateau and surroundings. - Nature Climate Change 2: 663-667. doi:10.1038/Nclimate1580. 
[51] Zavalloni, C., Gielen, B., De Boeck, H. J., Lemmens, C. M. H. M., Ceulemans, R., Nijs, I. (2009): Greater impact of extreme drought on photosynthesis of grasslands exposed to a warmer climate in spite of acclimation. - Physiologia Plantarum 136: 57-72. doi:10.1111/j.1399-3054.2009.01214.x.

[52] Zirbel, C. R., Bassett, T., Grman, E., Brudvig, L. A. (2017): Plant functional traits and environmental conditions shape community assembly and ecosystem functioning during restoration. - Journal of Applied Ecology 54: 1070-1079. doi: 10.1111/1365-2664.12885. 